\title{
BIOBLEACHING OF FLAX BY DEGRADATION OF LIGNIN WITH LACCASE
}

\author{
Rossica I. Betcheva, ${ }^{a}$ Hristina A. Hadzhiyska, ${ }^{a}$ Neli V. Georgieva, ${ }^{\text {b* }}$ and Lubov K. \\ Yotova $^{\mathrm{b}}$
}

Research on lignin biodegradation has become of great interest, due to the fact that lignin is one of the most abundant renewable materials, next to cellulose. Lignin is also the substance that gives color to raw flax fibers. In order to bleach the flax and to keep its tenacity high enough for textile applications, it is necessary to remove the lignin and partially to preserve the pectin. Lignin and pectin are the main constituents of the layer which sticks the flax cells together within the multicellular technical fiber. White-rot fungi and their oxidative enzymes, laccases and peroxidases (lignin peroxidases and manganese peroxidases), are being applied for the biobleaching of papermaking pulp, thereby reducing the need for environmentally harmful chemicals. Some data also suggest that it is possible to use other phenolytic enzymes, such as pure laccase, for this purpose. The objective of the present work was to study the possibility of bleaching flax fibers by pure laccase and combined laccase peroxide treatment, aimed at obtaining fibers with high whiteness and well-preserved tenacity.

Keywords: Laccase, Flax, Lignin degradation, Biobleaching, Laccase, Enzymes

Contact information: a: Department of Textile Chemistry, $b$ : Department of Biotechnology, University of Chemical Technology and Metallurgy, P. O. Box 1756, Sofia, Bulgaria, ${ }^{*}$ Corresponding author: tel.: +359 28163 307,E-mail: neli@uctm.edu

\section{INTRODUCTION}

Flax fibers contain, together with cellulose, considerable quantities of lignin and pectin. It is well known that the lignin is the second most abundant renewable compound on earth. Due to its hydrophobicity and complex random structure, lacking regular hydrolysable bonds, lignin is poorly biodegraded by most microorganisms (Aktas and Tanyolac 2003; Bennet et al. 2002). The lignin, together with the pectin, is located mainly in the layer that sticks the flax cells together within the flax fiber. For obtaining high quality linen textile materials with sufficient whiteness and hydrophilicity, it is necessary to remove pectin (which brings hydrophobicity, due to partial methylation, as well as association of the carboxyl groups with $\mathrm{Ca}^{2+}$ and $\mathrm{Mg}^{2+}$ ) and lignin (which is mainly responsible for the color of raw flax). Conventional pretreatment technologies apply sodium hydroxide combined with oxygen or chloride bleaching for this purpose. For the purposes of textile mechanical technologies (spinning and weaving) it is necessary to preserve the tenacity of flax fibers. This tenacity can be preserved if the flax cells remain stuck together. Such adhesion can be maintained if the pectin is not entirely removed. Therefore, we need a selective hydrolysation, capable of modifying only the lignin. $\mathrm{NaOH}$ is not a selective hydrolyser, since it destroys both the lignin and pectin. In 
searching for a specific lignin hydrolyser, it has been found that enzymes associated with the white rot fungus, which produces extracellular peroxidases, such as laccases, Mnperoxidase and lignin peroxidase, are among the best biodegraders of lignin (Georgieva et al. 2004; Hatakka 1994; Heinzkill and Messner 1997; Heinzkill et al. 1998). These enzymes can be used for biopulping, biobleaching, biotransformation, and bioremediation. They can be applied as auxiliaries in different industrial processes, replacing conventional chemicals such as alkalis, oxidizers, reducing agents, or acids (Petit-Conil et al. 2002; Rodrigues et al. 1999; Srebotnik and Hammel 2000). Regarding flax fibers processing, the lignin cleavage and removal are directly related to the degree of whiteness and to the quality of textile materials produced.

The objective of this work was to study the possibility of bleaching flax fibers by pure laccase and combined laccase-sodium peroxide treatment, aimed at obtaining fibers with high whiteness and well-preserved tenacity.

\section{EXPERIMENTAL}

\section{Enzymatic Treatment}

Unbleached flax fibres from "Rylski len-AD" Bulgaria and linen fabric (cotton/ flax: 50/50) were taken as reference samples. That textile materials were treated in the range of $30-60{ }^{\circ} \mathrm{C}$ for $1-5 \mathrm{~h}$ with $0.1 \mathrm{~g} / 1$ laccase (EC 1.10.3.2 Trametes $s p$. Laccase L603P from Biocatalyst; $0.125 \mathrm{~g}$ protein per $\mathrm{g}$ solid) in $100 \mathrm{mM} \mathrm{Na}$ - acetate/acetic acid buffer $\mathrm{pH}=5.0$. Control (conventional) bleaching was carried out under conditions close to those of the industrial technologies. That bleaching was accomplished by using $1 \% \mathrm{H}_{2} \mathrm{O}_{2}$ (o.w.f.) at $80{ }^{\circ} \mathrm{C}$ for $60 \mathrm{~min}$. at $\mathrm{pH}=9$ without stabilizer in bath ratio 1:10 without shaking. Combined (laccase-sodium peroxide) bleached samples were prepared from enzymatically treated textiles processed additionally with peroxide at $80{ }^{\circ} \mathrm{C}$ for $15 \mathrm{~min}$ and $50{ }^{\circ} \mathrm{C}$ for $60 \mathrm{~min}$., while the other bleaching parameters remained the same. Data obtained to characterize the effects of applied treatments were the average results from 3 parallel samples obtained at the same conditions.

\section{Analytical Measurements}

The bleaching effect of the treatments was measured by Datacolor equipment, and the CIELab parameter lightness $\left(\mathrm{L}^{*}\right)$ was used to evaluate the effectiveness of enzyme and bleaching treatments. Untreated flax fibers were used as a reference samples.

\section{Kappa Number Assay}

The content of lignin in samples studied was characterized by the Kappa Number assay. The flax fibers (1g each) were placed in a vessel containing $500 \mathrm{~cm}^{3}$ distilled water at $25{ }^{\circ} \mathrm{C}$ with careful stirring to which $100 \mathrm{~cm}^{3} 0.1 \mathrm{M} \mathrm{KMnO}_{4}$ and $100 \mathrm{~cm}^{3} 4 \mathrm{~N} \mathrm{H}_{2} \mathrm{SO}_{4}$ were added. The stirring duration was $10 \mathrm{~min}$. Then $20 \mathrm{~cm}^{3} 0.1 \mathrm{~N}$ KI were added to the solution, which was titrated with $0.2 \mathrm{~N} \mathrm{Na}_{2} \mathrm{~S}_{2} \mathrm{O}_{3}$. The Kappa number was measured by SCAN method (SCAN C 1:00) (Testing Committee Finland Sweden, 1977). 


\section{Physical and Mechanical Properties}

The physical and mechanical properties of textile samples were measured by a Dynamometer apparatus. In order to reveal the advantages of the combined enzymaticsodium peroxide bleaching, relative changes (R.C.) of the parameters obtained were calculated as follows:

$$
\text { R.C. }=\frac{\text { Specific Strength of Conventionally Bleached Material }}{\text { Specific Strength of Combined Bleached Material }} \times 100
$$

\section{RESULTS AND DISCUSSION}

The first stage of the experiment involved a treatment of flax fibers with pure laccase with enzyme activity $51 \mu \mathrm{mol} \cdot \mathrm{min}^{-1}$ at different temperatures. After that, all samples were bleached with $\mathrm{H}_{2} \mathrm{O}_{2}$, as described above. Colorimetric results, indicating efficiency in increasing the whiteness of fibers, are shown in Table 1. It can be seen that when the temperature of treatment increased, the degree of lightness went through a maximum at $40{ }^{\circ} \mathrm{C}$. This is the temperature where this enzyme shows maximum activity (Hadzhiyska et al., 2006). For the samples treated with a combination of enzyme and sodium peroxide bleaching, the same dependence could be observed. All results for the kappa ( $\kappa$ ) number showed the same trend. This could be considered as an indirect demonstration of the dependence between the whiteness of flax fibers and the content of lignin.

If one compares laccase versus lacasse-Na peroxide bleached fibers, one can see the following: Laccase processing was not, by itself, sufficient for obtaining flax fibers with a good appearance (whiteness). As the $\kappa$ numbers show, the quantity of lignin after the enzymatic treatment decreased, but it was still quite high compared to the value for the control sample. The fact that $\kappa$ numbers were lower could be explained in terms of changes occurring in the flax lignin.

It was anticipated that enzymatic destruction of lignin could lead to the acceleration of its removal by oxidative bleaching. For this purpose we studied the possibility for a shorter peroxide treatment of the laccase treated fibers. Results in Table 1 show that,

Table 1. Lightness and Lignin Content in Flax Fibers Treated with Laccase at

\begin{tabular}{|c|c|c|c|c|}
\hline \multirow[t]{2}{*}{$\mathrm{T}^{0} \mathrm{C} / 1 \mathrm{~h}$} & \multicolumn{2}{|c|}{ Enzyme treatment } & \multicolumn{2}{|c|}{$\begin{array}{l}\text { Additional bleaching with } \mathrm{H}_{2} \mathrm{O}_{2} \text { at } \\
80^{\circ} \mathrm{C} / 15 \mathrm{~min} \text {. }\end{array}$} \\
\hline & $L^{*}$ & $\kappa$ & $L^{*}$ & $\kappa$ \\
\hline & 1) 58.93 & 1) 15.23 & 2) 82.40 & 2) 5.5 \\
\hline 30 & 58.70 & 14.40 & 81.05 & 6.2 \\
\hline 40 & 60.65 & 13.69 & 82.73 & 6.2 \\
\hline 50 & 60.44 & 14.86 & 81.54 & 6.4 \\
\hline 60 & 59.78 & 14.87 & 80.44 & 6.6 \\
\hline
\end{tabular}
Different Temperatures 
for the enzymatically pretreated samples, 15 minutes bleaching with Na peroxide were enough to obtain results for lightness and kappa numbers that were similar to those for the control sample. Up to the present, there has been no technology for flax bleaching that can produce textile with good whiteness after only $15 \mathrm{~min}$. of sodium peroxide treatment at $80{ }^{\circ} \mathrm{C}$.

Data pertaining to the influence of the duration of the enzymatic treatment on the whiteness of flax fibers are given in table 2. The treatments were carried out at $40{ }^{\circ} \mathrm{C}$, bearing in mind the temperature dependences that were shown in Table 1.

Table 2. The Degree of Lightness of Laccase Treated Fibers at $40^{\circ} \mathrm{C}$

\begin{tabular}{|c|c|c|c|c|}
\hline \multirow[t]{2}{*}{$\begin{array}{l}\text { Duration of treatment } \\
\text { (h) }\end{array}$} & \multicolumn{2}{|c|}{$\begin{array}{l}\text { Enzymatic treatment at } \\
\qquad 40^{\circ} \mathrm{C}\end{array}$} & \multicolumn{2}{|c|}{$\begin{array}{l}\text { Enzymatic treatment at } 40^{\circ} \mathrm{C} \text { and } \\
\text { bleaching with } \mathrm{H}_{2} \mathrm{O}_{2} \text { at } \\
80^{\circ} \mathrm{C} / 15 \mathrm{~min} \text {. }\end{array}$} \\
\hline & $L^{*}$ & $\kappa$ & $L^{*}$ & $\kappa$ \\
\hline & 1) 58.93 & 1) 15.23 & 2) 82.40 & 2) 5.5 \\
\hline 1 & 60.65 & 13.69 & 82.73 & 6.2 \\
\hline 2 & 61.14 & 13.53 & 82.77 & 5.8 \\
\hline 3 & 61.29 & 13.52 & 83.43 & 5.7 \\
\hline 4 & 61.31 & 13.52 & 82.49 & 5.7 \\
\hline 5 & 61.50 & 13.21 & 82.46 & 5.6 \\
\hline
\end{tabular}

As can be seen from the data, there was not a very well pronounced time dependence of the enzyme effect.

The results obtained on linen fabric treated with laccase are shown in Table 3.

Table 3. CIElab Parameter $\left(\mathrm{L}^{*}\right)$ of Flax Fabric, Enzymatically Treated at $40^{\circ} \mathrm{C}$

\begin{tabular}{|c|c|c|}
\hline Duration of treatment $(\mathrm{h})$ & $\begin{array}{l}\text { L*before bleaching with } \\
\qquad \mathrm{H}_{2} \mathrm{O}_{2}\end{array}$ & $\begin{array}{l}\mathrm{L}^{*} \text { after bleaching with } \mathrm{H}_{2} \mathrm{O}_{2} \text { at } \\
80^{\circ} \mathrm{C} / 15 \mathrm{~min}\end{array}$ \\
\hline & 1) 61.04 & 2) 73.97 \\
\hline 1 & 66.43 & 78.38 \\
\hline 2 & 66.64 & 78.41 \\
\hline 3 & 66.72 & 78.63 \\
\hline 4 & 66.98 & 79.10 \\
\hline 5 & 67.21 & 79.21 \\
\hline
\end{tabular}

Results in Table 3 show, first of all, that the starting whiteness of the fabric was higher, due to the fact that it contained $50 \%$ cotton, and the flax fibers used were semibleached. The time dependence in case of fabric treatment was similar to that for the fiber treatment. Despite the fact that the fabric had a higher whiteness, when considering the untreated reference sample, the flax fibers had higher lightness after treatment, with vary- 
ing times of enzymatic treatment before peroxide bleaching. The comparison is given in Fig.1. These results can be rationalized based on the difference between the structure of woven linen textile material and the structure of flax fibers. Woven materials possess a considerably smaller contact reaction surface compared to that of fibrous material. For heterogenic reactions such as the bleaching of textiles in water media, a higher exposed area accelerates reactions occurring at the surface. That could be a possible explanation of the observed lower level of lightness for the fabric, compared to the flax fibers treated under the same conditions (Fig 1).

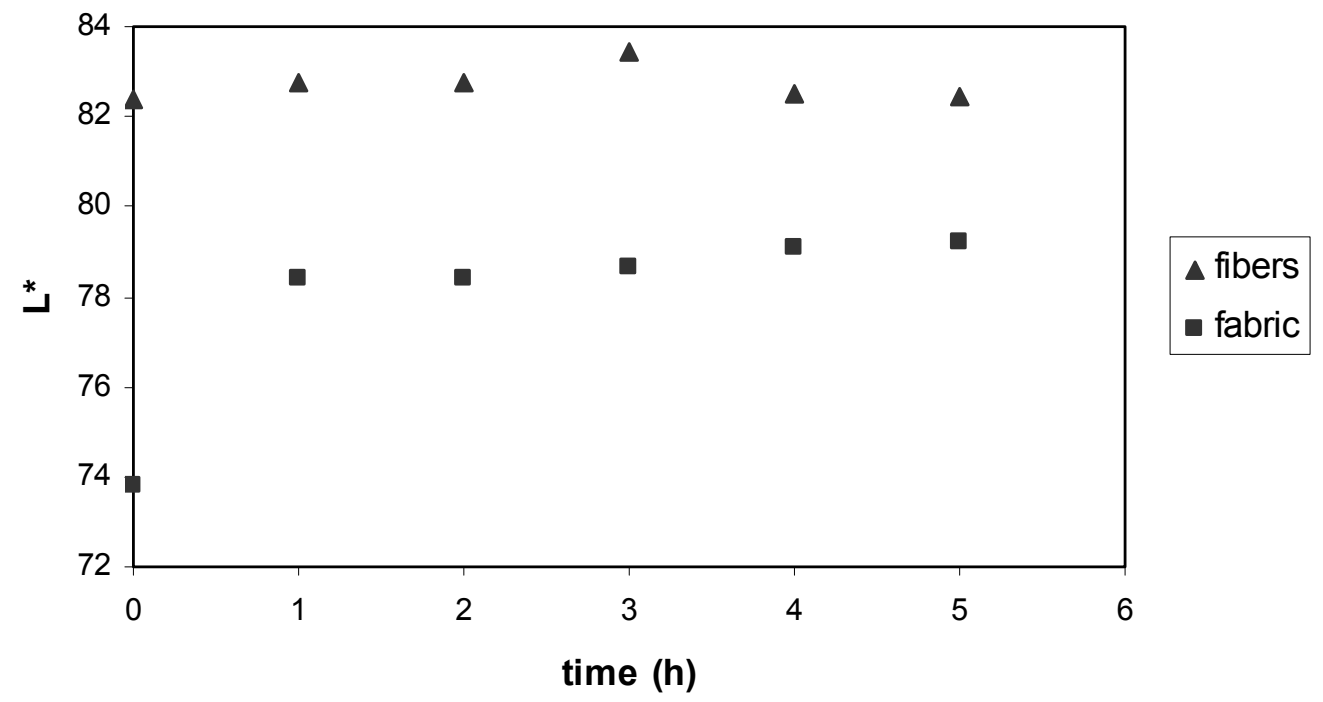

Fig.1. The degree of lightness of flax materials as a function of time of enzymatic treatment, prior to peroxide bleaching

Mechanical properties of flax fibers after treatment with Laccase L603P and after subsequent bleaching with hydrogen peroxide have been characterized by their specific strength. The results obtained are given in Table 4.

Table 4. Physical and Mechanical Properties of Flax Fibers, Treated with Laccase L603P for $1 \mathrm{~h}$; Reference Flax Fibers - $0.900 \mathrm{cN} / \mathrm{tex}$

\begin{tabular}{|c|c|c|c|}
\hline $\begin{array}{c}\text { Enzymatic treatment } \\
\text { temperature, } \\
\text { (one hour) }\end{array}$ & $\begin{array}{c}\text { Bleaching } \\
\text { with } \mathrm{H}_{2} \mathrm{O}_{2}\end{array}$ & $\begin{array}{c}\text { Specific strength } \\
\mathrm{cN} / \text { tex }\end{array}$ & $\begin{array}{c}\text { Relative change } \\
\%\end{array}$ \\
\hline $\begin{array}{c}\text { Conventional } \\
\text { bleaching(Control) }\end{array}$ & $\mathbf{8 0 ^ { \circ } / 1 \mathrm { h }}$ & $\mathbf{0 . 4 0 0}$ & $\mathbf{1 0 0}$ \\
\hline \multirow{2}{*}{30} & $80^{0} / 15^{\prime}$ & 0.525 & 131 \\
\cline { 2 - 4 } & $50^{\circ} / 1 \mathrm{~h}$ & 0.957 & 239 \\
\hline \multirow{2}{*}{40} & $80^{0} / 15^{\prime}$ & 0.526 & 131 \\
\hline \multirow{2}{*}{50} & $50^{0} / 1 \mathrm{~h}$ & 0.749 & 187 \\
\cline { 2 - 4 } & $80^{0} / 15^{\prime}$ & 0.526 & 131 \\
\hline \multirow{2}{*}{60} & $50^{0} / 1 \mathrm{~h}$ & 0.708 & 177 \\
\cline { 2 - 4 } & $80^{0} / 15^{\prime}$ & 0.501 & 125 \\
\hline
\end{tabular}


In the case of combined processing, we explored the possibility for the improvement of bleaching parameters in two ways. First we combined enzymatic treatment with sodium peroxide bleaching at higher temperature but shorter time. The second option that logically could lead to better final mechanical properties was a combined bleaching at lower temperature but longer time.

Experimental results for these treatments, given in Table 5, confirm that the combination of enzyme treatment with peroxide bleaching in all cases produced flax fibers with much higher strength than the conventional bleaching. These results showed also that the temperature of preliminary enzymatic treatment did not influence considerably the fiber tenacity when the bleaching was carried out at $80{ }^{\circ} \mathrm{C}$. When peroxide was applied at $50{ }^{\circ} \mathrm{C}$, there is a very strong dependence between the temperature of enzyme application and the fiber strength after bleaching. The decrease of fiber specific strength with the increase of the temperature of enzymatic treatment from 30 to $60{ }^{\circ} \mathrm{C}$ was very well pronounced. Flax fibers were definitely better-preserved when the peroxide bleaching is carried out at $50{ }^{\circ} \mathrm{C}$.

Table 5. Physical and Mechanical Properties of Flax Fabric, Treated with Laccase L603P for 1h, Reference Flax Fabric - 96.7 dN

\begin{tabular}{|c|c|c|c|}
\hline $\begin{array}{c}\text { Enzyme treatment } \\
\text { temperature, } \\
\text { (one hour) }\end{array}$ & $\begin{array}{c}\text { Bleaching } \\
\text { with } \mathrm{H}_{2} \mathrm{O}_{2}\end{array}$ & $\begin{array}{c}\text { Change in strength } \\
\mathrm{dN}\end{array}$ & $\begin{array}{c}\text { Relative change } \\
\text { in strength } \\
\%\end{array}$ \\
\hline $\begin{array}{c}\text { Conventional } \\
\text { bleaching (Control) }\end{array}$ & $\mathbf{8 0 ^ { \circ } / \mathbf { h }}$ & $\mathbf{3 3 . 8}$ & $\mathbf{1 0 0}$ \\
\hline \multirow{2}{*}{30} & $80^{\circ} / 15^{\prime}$ & 39.2 & 116 \\
\cline { 2 - 4 } & $50^{\circ} / 1 \mathrm{~h}$ & 45.0 & 133 \\
\hline \multirow{2}{*}{40} & $80^{0} / 15^{\prime}$ & 39.2 & 116 \\
\hline \multirow{2}{*}{50} & $50^{\circ} / 1 \mathrm{~h}$ & 45.1 & 133 \\
\hline \multirow{2}{*}{60} & $80^{0} / 15^{\prime}$ & 34.8 & 103 \\
\hline & $50^{0} / 1 \mathrm{~h}$ & 39.2 & 116 \\
\cline { 2 - 4 } & $80^{\circ} / 15^{\prime}$ & 34.3 & 103 \\
\hline
\end{tabular}

It can be concluded that the enzymatic treatment of samples with Laccase L603P (Biocatalyst) made it possible to carry out peroxide bleaching under milder conditions (a lower temperature and a shorter time for treatment). It can be supposed that the lignin could be destroyed to some extent during the preliminary enzymatic treatment. Probably the enzymatic treatment facilitates the subsequent final removal of lignin and its fragments during the peroxide bleaching. On the other hand, mild conditions could not destroy the pectin entirely, and this could be considered as the main reason for preserving the material's tenacity. 


\section{CONCLUSIONS}

The bleaching of textile materials containing flax fibers could be facilitated by a preliminary enzymatic treatment with L603P (Biocatalyst). After such a treatment, it was possible to achieve the target level of light reflectance with a just 15 minutes, rather than 60 minutes of treatment by the conventional method, applying only hydrogen peroxide.

The combined laccase (L603P) - Na peroxide bleaching could be carried out at a $50{ }^{\circ} \mathrm{C}$ for the oxidative bleaching. That could produce textile materials with high whiteness and very well preserved mechanical properties.

The effect of enzyme treatment could be explained in terms of selective hydrolysis of lignin by the laccase used and better preservation of pectin under these peroxide bleaching conditions.

\section{Symbols Used:}

L * - CIELab Lightness

o.w.f. - out of weight of fibers

$\chi$ - kappa number

$\mathrm{h}$ - time in hours

\section{REFERENCES CITED}

Aktas, N., and Tanyolac, A. (2003). "Reaction condition for laccase catalyzed polymerization of catechol," Bioresource Technology 87, 209-214.

Bennet, J., Wunch, K., and Faison, B. (2002). "Use of Fungi in Biodegradation," In: Environmental Microbiology, Ch. Hurst (ed.), ASM Press Washington, D.C., 960971.

Georgieva, N., Yotova, L., Valchev, I., Chadjiiska, Ch., and Arizanov, V. (2004).

"Biotransformation of lignin in linen by degradation with Phanerochaete chrysosporium," Proceedings Bioprocess System Dec. 6 - 8, 4(10), Sofia.

Hadzhiyska, H., Calafell, M., Gibert, J.M., Daga, J.M., and Tzanov, T. (2006). "Laccaseassisted dyeing of cotton," Biotechnology Letters 28 (10), 755-759.

Hatakka, A. (1994). "Lignin modifying enzymes from selected white-rot fungi: production and role in lignin degradation," FEMS Microbiol. Rev.13, 125-135.

Heinzkill, M., and Messner, K. (1997). "The Lignolytic System of Fungi," In: Fungal Biotechnology, T. Anke (ed); Chapman and Hall, Weinheim, 213-276.

Henzkill, M., Bech, L., Halkier, T., Schneider, P., and Anke, T. (1998). "Characterization of laccase and peroxidases from wood-rotting fungi (Finaly Coprinaceae)," Appl. Environ. Microbiol. 64 (5), 1601-1606.

Petit-Conil, M., Semar, S., Niku-Paavola, M.L., Sigoillot, J.C., Asther, M., Anke, H., and Viikari, L. (2002). "Potential of laccases in softwood-hardwood high-yield pulping and bleaching," In: Biotechnology in the Pulp and Paper Industry, Progress in Biotechnology L. Viikari and R. Lantto. (eds.) Elsevier, Amsterdam, 21, 193-201.

Rodriguez, E., Pickard, M., and Vazquez-Duhalt, R. (1999). "Industrial dye decolorization by laccases from ligninolytic fungi," Curr. Microbiol. 38 (1), 27-32. 
Srebotnik, E., and Hammel, K. (2000). "Degradation of nonphenolic lignin by the laccase/1-hydroxybenzotriasole system," J. Biotechnol. 81, 179-188.

Testing Committee Finland Sweden, (1977). Chemical Pulps "Kappa number," Scandinavian pulp, paper and board, June.

Article submitted: Dec. 7, 2006; First round of reviewing completed: Jan. 15, 2007;

Revision accepted: Jan. 23, 2007; Article published Jan. 25, 2007 